\title{
Maids, nannies and their work - views of Nigerian female employers
}

\author{
Nu'uman Mohammed Habib, Ph.D \\ Department of Sociology \\ Bayero University, Kano. Nigeria.
}

\begin{abstract}
This paper explores the views of employers of maids and nannies - girls aged 8 to 16 who help look after their children and household, thus enabling them to pursue education and career. The women employers are privileged, high status occupants, while the maids and nannies, who are poor rural, took up the employment to help put food on the table for their families. However, taking up such jobs not only exposes the child maids and nannies to several hazards, it denies them the chance for education. In interviews with the employers, the paper found that without the services of the maids and nurses, many of them would have been severely constrained to pursue higher education or career. In other words, as long as the conditions that propels young children to seek jobs as domestic workers persist, and for as long as there are no alternatives for the privileged urban-based woman, child domestic work will continue.
\end{abstract}

\section{INTRODUCTION}

One of the disturbing statistics coming out of Nigeria is the reported high number of children that are not enrolled in school. According to UNICEF, one in every five of the world's out-ofschool children is in Nigeria even though the Nigerian constitution makes it not only free but compulsory for all children to attend primary schools. Theoretically, therefore, there was no reason why any of Nigeria's children should be out of school. While it is accepted that the future of Nigeria like it is with all other nations lies and is intimately tied to the present status of its children, it should certainly be a source of worry when it is realized that as many as 10.5 million of its children aged between 5-14 years are not in school (UNICEF, 2019). Equally worrisome is the destination of these children: if they are not in school, where are they?

This paper has its impetus in the observation around a university campus of young children, all of them girls, of school age, tending to babies and toddlers, serving as nannies and maids, as the mothers of those babies and toddlers attend classes. These children that roam the campus with babies strapped to their backs must obviously be part of those millions of out-of-school Nigerian children. The student-employers of the maids should also have a story to tell about their employees and what purposes such employment serves. If they must employ maids and nannies, why must they employ children?

To the extent that these maids and nannies are children, this study falls within the purview of research into child labour and the consequences it has for the child, her future and that of the nation where such potentially useful segment of the population is left out-of-school and uneducated. We shall, therefore, discuss issues related to child labour before returning to the questions raised above.

\section{CHILD LABOUR}

Scholars have addressed the issue of child labour seeking to distinguish between "work that profits children and work that brings profit only to the employer" (Hine, 1908). Child labour 
refers to the employment of children in any work that deprives children of their childhood, interferes with their ability to attend regular school, and that is mentally, physically, socially or morally dangerous and harmful (ILO, 2015).

The Convention on the Rights of the Child which was adopted and opened for signature, ratification and accession by General Assembly resolution 44/25 of 20 November 1989 provides under Article 6 that:

1. States Parties recognize that every child has the inherent right to life.

2. States Parties shall ensure to the maximum extent possible the survival and development of the child.

Speaking specifically to education Article 28 obliges:

1. States Parties recognize the right of the child to education, and with a view to achieving this right progressively and on the basis of equal opportunity, they shall, in particular:

(a) Make primary education compulsory and available free to all;

(b) Encourage the development of different forms of secondary education, including general and vocational education, make them available and accessible to every child, and take appropriate measures such as the introduction of free education and offering financial assistance in case of need;

(c) Make higher education accessible to all on the basis of capacity by every appropriate means;

(d) Make educational and vocational information and guidance available and accessible to all children;

(e) Take measures to encourage regular attendance at schools and the reduction of drop-out rates.

Countries, including Nigeria, have, in addition to international laws and conventions, local laws that seek to further entrench the rights of the child to safety, security, education, and wellbeing among others. As a complement to the Convention on the Rights of the Child, CRC, the Nigeria Labour Act details what types and nature of labour the child and young person should be engaged in. It provides:

59. (1) No child shall-

(a) be employed or work in any capacity except where he is employed by a member of his family on light work of an agricultural, horticultural or domestic character approved by the Minister; or

(b) be required in any case to lift, carry or move anything so heavy as to be likely to injure his physical development.

(3) A young person under the age of fourteen years may be employed only-

(a) on a daily wage; (b) on a day-to-day basis; and (c) so long as he returns each night to the place of residence of his parents or guardian or a person approved by his parents or guardian: Provided that, save as may be otherwise provided by any regulations made under section 65 of this Act, this subsection shall not apply to a young person employed in domestic service.

(4) No young person under the age of sixteen years shall be employed in circumstances in which it is not reasonably possible for him to return each day to the place of residence of his parent or guardian except-

(a) with the approval of an authorized labour officer; and (b) on a written contract (which, notwithstanding any law to the contrary, shall not be voidable on the ground of incapacity to contract due to infancy) conforming with Part I of this Act: Provided that, save as may be otherwise provided by any regulations made 
under section 65 of this Act, this subsection shall not apply to a young person employed in domestic service.

(5) No young person under the age of sixteen years shall be employed-

(a) to work underground; or (b) on machine work; or (c) on a public holiday.

(6) No young person shall be employed in any employment which is injurious to his health, dangerous or immoral; and, where an employer is notified in writing by the Minister (either generally or in any particular case) that the kind of work upon which a young person is employed is injurious to the young person's health, dangerous, immoral or otherwise unsuitable, the employer shall discontinue the employment, without prejudice to the right of the young person to be paid such wages as he may have earned up to the date of discontinuance.

(7) No person shall continue to employ any young person under the age of sixteen years after receiving notice either orally or in writing from the parent or guardian of the young person that the young person is employed against the wishes of the parent or guardian: Provided that this subsection shall not apply to a young person employed under a written contract entered into with the approval of an authorized labour officer.

(8) No young person under the age of sixteen years shall be required to work for a longer period than four consecutive hours or permitted to work for more than eight working hours in any one day: Provided that, save as may be otherwise provided by any regulations made under section 65 of this Act, this subsection shall not apply to a young person employed in domestic service.

60. (1) Subject to this section, no young person shall be employed during the night.

(2) Young persons over the age of sixteen years may be employed during the night in the following industrial undertakings or activities which by reason of the nature of the process are required to be carried on continuously day and night, that is to say-

(a) in the manufacture of iron and steel, in processes in which reverberatory or regeneratory furnaces are used and in the galvanizing of sheet metal or wire (except the pickling process); (b) glass works; (c) manufacture of paper; (d) manufacture of raw sugar; and (e) gold mining reduction work.

(3) Young persons over the age of sixteen may be employed during the night in cases of emergency which-

(a) could not have been controlled or foreseen; (b) are not of a periodical character; and (c) interfere with the normal working of an industrial undertaking.

(4) In this section, "night" means a period of at least twelve consecutive hours, including-

(a) in the case of young persons under the age of sixteen years, the interval between ten o'clock in the evening and six o'clock in the morning; and (b) in the case of young persons over the age of sixteen years but under the age of eighteen years, a prescribed interval of at least seven consecutive hours falling between ten o'clock in the evening and seven o'clock in the morning.

However, despite the foregoing legislations and conventions, it is not in doubt that not all work that is done by children is considered child labour. Any work that children do that is not harmful to their mental and physical development is generally regarded as positive, it may even be a necessary part of their socialization and development. Some labour may not only put money into the pockets of the children, it may expose them to necessary life survival skills such as savings and investment decisions. These kinds of activities contribute to children's development and to the welfare of their families; they provide them with skills and experience, and help to prepare them to be productive members of society during their adult life. 


\section{Significance of the study}

In many countries maids and nannies are hired for baby-sitting and the general housekeeping including cooking, washing, cleaning and other incidental work around the home (Rollins, 1985). Some maids are also known to play additional roles, including taking children to and from school, as well as minding the house while the owner is out to work or otherwise engaged. In developing countries like Nigeria, where working mothers may have no access to day care facilities for their children at the work place, the maid fills in the void. A maid or nanny not only provides service to the needy persons of the society but also, for many a woman of child-bearing age, not accessing such service may jeopardize her participation in the formal workforce or her quest for education. The present study will give us an insight into this underexplored area of domestic service from the perspective of the employer.

\section{Objectives of the study}

The objectives of the study are:

1. To explore the characteristics of the employers of the maids and nannies.

2. To find out what views and opinions the employers hold of the maids and nannies and the work that they do for them?

\section{LITERATURE REVIEW AND ANALYTICAL FRAMEWORK}

Women and men have been analyzed in terms of the work that they do on account of their gender difference. Although division of labour may seem natural, scholars say it is not a neutral process. Acker (1989) points out that due to gender hierarchies, skewed and manipulated to favour men, women are paid less even when they do comparable jobs. Certain occupations and jobs were also elevated and preferred once they carry the toga "men's work" and those levied "women's work" are demeaned (Reskin and Roos, 1990)

Hartmann (1976) blame women's lowly position in the labour market to the combined effects of capitalism and patriarchy. As a consequence of differential gender treatment, social and historical circumstances, women the world over, have experienced marginalization and discrimination in all spheres, including access to education and jobs. The work that they do, even that which they are biologically equipped to do - such as child bearing - are not accorded the prestige and recognition it deserves. Chores that they do around the house are unremunerated on account of it being regarded as part of the housewife duties.

Women only began to join the formal labour force due to necessities when men went to the war fronts and there was shortage of labour to run the factories. This work was considered an interim one, since on the return of the men from the war fronts, the women were going back to their house chores. Expanding production and changing opinions, and the fact that women were doing jobs at a fraction of what men were being paid meant that women never went back to the kitchen. They stayed, but as unequal partners.

In the case of colonial countries, the hierarchy of privileges put the woman of the colonies much lower, below the black man, who is subordinated to the colonial occupiers. Karimi (2010) talking of Kenya:

Historically, paid domestic labor originated in the colonial period. As in all patriarchal societies, there existed in Kenya a marked division of labor across gender lines. It is interesting to note that domestic labor in colonial Kenya was mainly the purview of men. It was the male members of the family who left their own homes, mostly in the rural areas, to work in white households as a means of earning a livelihood. p.152. 
As particular jobs and occupations are abandoned by men, women move in and take over. The post-independence period saw the feminization of domestic labor in Kenya, with more women joining the workforce and gradually constituting the larger percentage of domestic workers (Karimi 2010). The more educated and affluent, those that stepped into the shoes of the former colonialists, employ their rural folk in domestic labour, especially girls, in large numbers into this sector.

Moser $(2014,1993)$ has developed and refined a framework which has been found useful in not only understanding the "triple bind" in which women are held, the framework she developed has helped to design strategies to get women out of the shackle. "Gender roles" and "gender needs" was responsible for why educated working women hire and make use of domestic labour. In most societies Moser (1993) argues, must fulfill three main roles:

Reproductive: This refers not only to women's childbearing role, but also their child rearing one. Women engage in various activities that ensure the maintenance and reproduction of the labour forces.

Productive: This refers to the women's role as income earners (often in agriculture or the informal sector). Though they are often secondary income earners, there are many cases when they are the sole income earner (such as in female headed households).

Community: This refers to women's collective work at the community level.

Women have to balance these three roles, whereas men generally only have a productive role (though they may be involved in "community politics" where they organise at the formal political level).

\section{Gender Needs}

It is the fulfillment of these "gender roles" that determines people's "gender needs". Such needs can be further broken down into "practical gender needs" and "strategic gender needs" (Moser, 1996).

\section{a. Practical Gender Needs}

Practical gender needs refer those needs of men and women as defined by their existing engendered roles within society, in which, as mentioned, women must fulfill three roles while men usually fulfill one. Practical needs and practical policies are concerned with the effective fulfillment of these socially defined roles; that is, they do not seek to change the status quo.

\section{b. Strategic Gender Needs}

In contrast, strategic needs and strategic policies are directly concerned with changing the status quo: challenging socially defined roles and tackling gender subordination in society.

\section{METHODS AND MATERIALS}

This study surveys those university students that come to school with their maids, thus they are the target population. The initial four respondents came from a postgraduate class taught by the researcher. During the cause of discussions in the class, some heat was raised regarding the employment of young girls as maids and nannies; tempers were doused and channeled to more productive ends when those for and against the practice were asked to give their reasons for the positions they adopted. Additional respondents were recruited for the study by these initial four students in a snowball sampling strategy, resulting in a total final population that of 23 students took part in the study. It is important to add that there are probably ten times this 
number of students that may have met the criteria for participation, so this number is only of those that were referred and agreed to be part of the research.

For a respondent to fulfill the criteria for inclusion she, in addition to being a student (graduate or undergraduate), must also have a maid that she brings along to the school, and the maid or nanny is below 16 years of age.

All respondents were briefed about the study and their consents sought before being interviewed. The majority of the Interviews were conducted in the researcher's office in the presence of respondent's maid, the person or persons that suggested her to the researcher, or both. Inclement weather was one reason why the only two interviews were held outdoors, not inside the researcher's office. The interviews were recorded and transcribed.

\section{Characteristics of employers of nannies and maids}

\section{RESULTS AND DISCUSSION}

As has been explained all the respondents are female students at a university where this study was carried out. Table I shows the age distribution of the respondents:

Table I: Age Distribution of Respondents

\begin{tabular}{|l|c|c|}
\hline Age & Frequency & Percentage \\
\hline $20-24$ & 6 & 26.08 \\
\hline $25-29$ & 13 & 56.52 \\
\hline $30-34$ & 4 & 17.40 \\
\hline TOTAL & $\mathbf{2 3}$ & $\mathbf{1 0 0}$ \\
\hline
\end{tabular}

The youngest respondent is aged 20 and the oldest is 34 . However, more than 50 percent of the respondents are aged between 25 and 29 years old. About a quarter of the respondents fall within the age band $20-24$, while those in the age range $30-34$ make up 17 percent. All the respondents are well within their most fecund stage. Again, as one of the criteria of their inclusion was having a baby which made them bring along a maid or nanny to school, it bears no repeating that these respondents are in school, in part, because part of the burden of child care is taken care for them by these employees.

Next we turn to the number children that the respondents have, where both the actual number was asked, as well what their desired family size.

Table 2: Number of Children of Respondents

\begin{tabular}{|l|c|c|}
\hline Number of Children & Frequency & Percentage \\
\hline 1 child only & 12 & 52.17 \\
\hline 2 children & 10 & 43.47 \\
\hline 3 children & 1 & 4.34 \\
\hline Total & $\mathbf{2 3}$ & $\mathbf{1 0 0}$ \\
\hline
\end{tabular}

Only one respondent has 3 children, the majority, 52\% of the respondents, report having only one child, ten others have 2 children. All the respondents also gave indication that they have not yet attained their desired family size, 4 children, for the majority, with one aiming for 6 . This being the case, the demand for maids and nannies is not likely to abate anytime soon.

Another reason why the respondents will continue to require the services of maids and nannies is because of their employment status - 12 of them hold jobs as teachers or administrators, 1 person works with a bank, while the others are actively searching. 


\section{Characteristics of nannies and maids}

All the nannies and maids were sighted by the researcher during the study but none of them was formally interviewed as they were not part of the study, only their employers were. Age of the nannies and maids were provided by the respondents relying on one or more sources: the girl, her parents or guardian, or her own estimation based on the child's built and physique. With none of them having a birth certificate, the age of the maids and nannies is taken as given.

Table 2. Age of Maids and Nannies

\begin{tabular}{|l|c|c|}
\hline Age & Frequency & Percentage \\
\hline 8 & 2 & 8.69 \\
\hline 9 & 1 & 4.34 \\
\hline 10 & 4 & 17.39 \\
\hline 11 & 3 & 13.04 \\
\hline 12 & 8 & 34.78 \\
\hline 13 & 3 & 13.04 \\
\hline 14 & 1 & 4.34 \\
\hline 15 & 1 & 4.34 \\
\hline TOTAL & $\mathbf{2 3}$ & $\mathbf{1 0 0}$ \\
\hline
\end{tabular}

The oldest of the maids is aged 15 and the youngest are aged 8. Thirty-four percent of the maids are aged 12 , with the next highest - 17\% being those aged 10 , followed by $13 \%$ for those aged 11 and 13. The significance of the ages is captured in the answers given to the question the respondents were asked regarding what they consider in recruiting maids. Referring specifically to age, respondents opined thus:

I do not want someone who is too young, certainly not younger than 10. I had one that was young, 7 or so, and she was bedwetting; I sent her back! (Talatu)

You are in a dilemma, if you she is too young she may not be able to do some of the things you want, I need someone that is capable. (Aisha)

It is those in the range of seven to nine, that are more reliable and whose stay may be guaranteed. From around age 14 - 15 you are most definitely going to lose your maid, she will be asked to return home to be married off. (Binta)

From the views above, we see the respondents emphasizing at least three things: they recruit maids and nannies that are capable of doing the tasks they were employed to do, certainly not a loafer; stability, rather than high turnover, of maids and nannies - such that the employer does not have be on edge not sure the maid is going to stay or go, and, lastly, they want an employee that is not herself in need of care. One respondent, however, qualified the age issue this way:

Some of these girls may be young, age-wise, but what they can do will amaze you, don't always be deceived by age. (Asabe)

\section{Work ethics of maids and nannies}

Employers were divided on the work ethics of the maids and nannies in their service. Aisha, a respondent was full of accolades for her current nanny:

This girl is dependable and a workaholic, she is always doing one thing or the other around the house. I am the one telling her to go and rest, but she would not. 
A similar view was echoed by another respondent:

Even before I wake up, this girl would have been up sweeping, dusting and mopping. My baby is just six months, she handles her just fine. (Safiya)

Hajiya, however, has harsh view of maids and nannies. In stark contrast to the views of her corespondents reported above, it is her position that maids and nannies are "a necessary evil". According to her:

Within a span of 10 months, I changed three. First one was always sleeping as if she had sleeping sickness, the second one kept coming back from errands to say she lost the money I gave her to buy things, the third one, I sacked because in her second week with me I found some of my items kept hidden in her room. She had no answer as to why they were in her luggage. If that one had stayed longer she would have stolen us blind. My frank view is that these girls are a necessary evil, if I could do without them, I would. (Hajiya)

\section{Caring for the maids and nannies}

Respondents were asked whether, in their own opinion, the maid and nannies in their employment are happy and satisfied with how they are being treated in the house. Without exception, all the respondents scored themselves as fair employers. They point to the fact that they do not abuse the children physically or emotionally, since they consider them like their own:

The girl has been with me six months; I don't ever recall me scolding her. I can't bring myself to abuse her not to talk of beating. I am not the type. (Safiya)

'Yar amanah ce (she is a trust), if she begins to appear wayward she will be returned by me to her parents. (Gaji)

Others also alluded to their generosity to the girls and their parents:

This Ramadan is the third she is spending here. If I had not been good to her and her family she would have since left. (Amina)

She eats what we eat, and sleep with my two and a half-year old, I consider them sisters. She is family. (Rabi)

\section{CONCLUSIONS}

This focus of this paper is employers of child maids and nannies, those women whose desire to pursue education and or career, while not putting child bearing on hold, makes them to secure the services provided by the maids and nannies. All of the women regard their employees as vital to them and employ strategies to get the best out of them.

Beginning from recruitment, the employers have preference for early teens - since they are more likely to stay in employment longer. Older teens, 15 and 16, are the least preferred on account of the fear that they may be recalled back to the villages to be married off, being considered by their parents as ripe for marriage. Employers also want competent, trust worthy and reliable maids and nannies.

Employers rated themselves high when it comes to the way they treat their maids and nannies. Both the scholarly literature and the popular press are replete with the horrors that maids and nannies, as domestic workers, encounter. That the respondents in this study are painting a different picture of themselves should invite further scholarly analysis to compare the reported self-assessment of the employers with that of the employees. In this study only the voices of the employers were heard. 


\section{References}

Acker, Joan (1989). Doing Comparable Worth. Philadelphia, Penn: Temple University Press.

Hartmann, Heidi (1976). “Capitalism, Patriarchy and Job Segregation by Sex.” In Martha Blaxall and Barbara Reagan, eds., Women and the Workplace. Chicago University Press.

Hine, Lewis (1908) cited in Introduction to Global Child Labor available at: http://www.continuetolearn.uiowa.edu/laborctr/child_labor/Accessed May 16, 2016

International Labour Organisation. 2015. What is child labour? Available at: http://www.ilo.org/ipec/facts/langen/index.htm. Accessed Mar 15, 2015

Karimi, Vicky (2010). Criminal Exploitation of Women and Children: Domestic Workers in Kenya. In: Obi N.I. Ebbe and Dilip K. Das eds. (2010). Criminal abuse of women and children: an international perspective. New York : Taylor and Francis Group, LLC

Labour Act. Chapter 198: Laws of the Federation of Nigeria 1990. Available at: http://www.nigeria law.org/LabourAct.htm. Accessed Aug 17, 2011

Caroline O. N. Moser (1993). Gender planning and development: theory, practice, and training. Routledge.

(2014). Gender planning and development: revisiting, deconstructing and reflecting. DPU60 Working Paper Series: Reflections NO. 165/60

Obi N.I. Ebbe and Dilip K. Das eds. (2010). Criminal abuse of women and children: an international perspective. New York : Taylor and Francis Group, LLC

Rollins, Judith (1985). Between Women: Domestics and their Employers. Philadelphia: Temple University Press. 